\title{
Dihydrocodeine Bitartrate
}

National Cancer Institute

\section{Source}

National Cancer Institute. Dihydrocodeine Bitartrate. NCI Thesaurus. Code C47490.

A synthetic opioid analgesic. Dihydrocodeine bitartrate mimics the actions of the endogenous opioid peptides due to its agonistic effects on the opioid receptors. Stimulation of the mu receptors produces the typical narcotic effects of analgesia, miosis, euphoria, respiratory depression, sedation, physical dependence and bradycardia. Dihydrocodeine bitartrate is twice as potent as codeine and has one third of the potency of morphine. This analgesic is used for the relief of moderate to moderately severe pain. 